Bundesgesundheitsbl 2013 $\cdot 56: 1565-1576$ DOI 10.1007/s00103-013-1845-8

Published Online: 24. Oktober 2013

(c) Springer-Verlag Berlin Heidelberg 2013

T. Harder ${ }^{1} \cdot$ C. Remschmidt ${ }^{1} \cdot$ G. Falkenhorst ${ }^{1} \cdot$ R. Zimmermann ${ }^{2} \cdot$ H. Hengel ${ }^{3}$. T. Ledig ${ }^{4} \cdot$ H. Oppermann 5 . S. Zeuzem ${ }^{6} \cdot$ S. Wicker ${ }^{7}$

${ }^{1}$ Immunization Unit, Department of Infectious Disease Epidemiology, Robert Koch Institute, Berlin

${ }^{2}$ HIV/AIDS, STI and Blood-borne Infections Unit, Department for Infectious

Disease Epidemiology, Robert Koch Institute, Berlin

${ }^{3}$ Institute of Virology, University Medical Center Freiburg

${ }^{4}$ Medical Practice, Ditzingen

${ }^{5}$ State Office for Consumer Protection, Saxony-Anhalt, Magdeburg

${ }^{6}$ Department of Internal Medicine 1, University Hospital, Frankfurt/Main

${ }^{7}$ Occupational Health Service, University Hospital, Frankfurt/Main

\title{
Background paper to the revised recommendation for hepatitis $B$ vaccination of persons at particular risk and for hepatitis B postexposure prophylaxis in Germany
}

- Indication group 2: Persons at increased risk of non-occupational exposure

- Indication group 3: Persons at increased risk of occupational exposure

Relevant examples are given for each indication group.

- STIKO recommends hepatitis B vaccination of these risk groups, without prior routine serological testing, except in special situations.

- For all groups, STIKO recommends assessing vaccination success by antiHBs testing 4-8 weeks after the third vaccine dose. An anti-HBs level of $\geq 100$ IU/l is considered indicative of successful vaccination against hepatitis B.

the following three indication groups (in addition to a recommendation for at-risk travellers):

- Indication group 1: Persons at risk of severe hepatitis B due to existing or expected immunodeficiency or suppression or due to other preexisting diseases
For low-responders (anti-HBs 1099 IU/l), STIKO recommends vaccination with one additional vaccine dose, followed by anti-HBs testing. If anti-HBs is still $<100 \mathrm{IU} / \mathrm{l}$, two more doses should be administered. Controversy exists as to which approach should be followed if anti-HBs is still
$<100$ IU/l after six doses of hepatitis B vaccine.

- For non-responders (anti-HBs $<10$ IU/l), STIKO recommends testing for HBsAg and anti-HBc to exclude chronic infection. If both parameters are negative, the recommendations for low-responders should be followed.

- STIKO does not recommend routine booster immunizations after successful primary vaccination (anti-HBs $\geq 100$ IU/l). Exceptions are made in patients with humoral immune deficiency for whom annual testing of anti-HBs (and booster immunization if anti-HBs $<100 \mathrm{IU} / \mathrm{l}$ ) is recommended, as well as in persons who are at particularly high individual exposure risk (anti-HBs testing after 10 years; booster immunization if anti-HBs $<100 \mathrm{IU} / \mathrm{l})$.

Thomas Harder, Cornelius Remschmidt, Gerhard Falkenhorst: Executive Secretariat of STIKO. Hartmut Hengel, Thomas Ledig, Hanna Oppermann, Sabine Wicker: Members of the German Standing Committee on Vaccination (STIKO). 
- For persons who were vaccinated against hepatitis B during infancy and who later enter one of the risk groups, STIKO recommends vaccination with one dose of hepatitis B vaccine, followed by anti-HBs testing.

\section{Postexposure prophylaxis} against hepatitis $B$

- STIKO recommends assessing the HBsAg status of the index patient (i.e., the "donor"). If the donor is HBsAg positive or if HBsAg status of the donor cannot be assessed, postexposure prophylaxis is recommended according to the vaccination status of the exposed person.

- In fully vaccinated exposed persons, management depends on the result of the most recent anti-HBs test result. Persons with anti-HBs $\geq 100$ IU/l tested within the last 10 years are considered fully protected. All others should receive postexposure prophylaxis depending on the current and most recent anti-HBs levels.

- In incompletely vaccinated exposed persons, the current anti-HBs level should be determined. Further management depends on the current and most recent anti-HBs levels. Furthermore, the vaccination series should be completed.

- In unvaccinated persons, anti-HBs, $\mathrm{HBsAg}$, and anti-HBc should be determined to decide on further procedures.

For the full text of the STIKO recommendation, see http://www.stiko.de (in German).

This paper reports the scientific evidence on which the revision of STIKO's previous recommendations is based.

\section{Introduction}

The aim of the revision was to adapt the recommendations for hepatitis B vaccination of persons at particular risk and for postexposure prophylaxis to bring them in line with the current state of knowledge and to increase their feasibility. The revision does not affect the recommendations for standard vaccination against hepati- tis B during the first year of life, which remains unchanged (see http://www.stiko. de).

Following the methodology of STIKO, the recommendation was adapted after conducting orientating and systematic literature searches on the following questions:

1. Which population subgroups are at increased risk of hepatitis B infection or complications?

2. What is the duration of protection against hepatitis B after primary vaccination?

3. Does duration of protection depend on the level of anti-HBs after primary vaccination?

The results of these searches, which are summarized below, were used to revise the classification of risk groups and the guidance on serological testing, booster immunization as well as postexposure prophylaxis.

\section{The goal of hepatitis B vaccination}

The goal of vaccination against hepatitis B is to prevent acute clinical hepatitis and chronic infection by the hepatitis $B$ virus (HBV) in Germany. Beyond that, all types of HBV infection (including occult infections) should be prevented.

\section{Hepatitis B: virus, disease, and vaccination}

Hepatitis B is inflammation of the liver caused by HBV, a virus that occurs worldwide. It is transmitted sexually and through exposure to infectious blood or body fluids. The majority of infected immunocompetent adults recover spontaneously from disease. However, in 5\%-10\% of infected patients, disease progresses towards chronic infection, which can result in liver cirrhosis and liver cancer. Chronic disease is more common in children and immunocompromised individuals [2]. According to $\$ 6$ of the German Protection against Infection Act (Infektionsschutzgesetz, IfSG) acute hepatitis B has been a notifiable disease in Germany since 2001.

Vaccination against hepatitis $B$ has been recommended for all infants in Ger- many since 1995. Furthermore, it is recommended for persons at increased risk for hepatitis B infection. In infants, primary vaccination consists of at least three intramuscular doses of hepatitis B vaccine, which should be administered preferably on a 3-(4) dose schedule at ages 2, (3), 4, and 12 months. After the age of 12 months, a three-dose schedule $(0,1,6$ months $)$ is recommended. Two single antigen vaccines are available in Germany, Engerix $\mathrm{B}^{\oplus}$ (GSK) and Recombivax $\mathrm{HB}^{\circledast}$ (Mer$\mathrm{ck}$ ); additionally, an adjuvant containing a single formulation vaccine, Fendrix ${ }^{\infty}$ (GSK), is available. Combination vaccines used for the vaccination of infants and children in Germany include Infanrix hexa ${ }^{\circledR}$ (GSK) and Heyxon ${ }^{\oplus}$ (Sanofi Pasteur MSD); Twinrix ${ }^{\oplus}$ (GSK) is used for the vaccination of adults. All these vaccines contain HBsAg produced by DNA recombinant technology and expressed in yeasts.

\section{Epidemiology of hepatitis B in Germany}

In 2012, 1670 cases of hepatitis B were reported to the Robert Koch Institute (RKI), of which 679 met the reference case definition. Compared to 2011 (812 cases according to the reference case definition), the number of cases decreased by $16 \%$ [3]. In 2012, the incidence of reported acute hepatitis B in Germany was 0.8 per 100,000 residents, with men $(1.2$ per 100,000$)$ being more frequently affected than women $(0.5$ per 100,000$)$. Incidence was highest in men and women aged 30-39 years (2.0 per 100,000 and 0.9 per 100,000 , respectively). Only six cases in children and adolescents below 15 years of age were reported to RKI in 2012, equalling the median of the past 5 years. As compared to 20012005 (median: 41 cases), the number of cases has declined, most likely due to the introduction in 1995 of standard immunization against hepatitis $B$ for all infants.

As far as can be concluded from the notification data from 2012, sexual transmission was the most prevalent mode of infection, followed by household contact with an $\mathrm{HBV}$ carrier, intravenous (i.v.) drug use, and hemodialysis. Of 525 acute HBV cases with information on vaccination status available, 494 (94\%) cases were not vaccinated against hepatitis $B$. 
It should be borne in mind that, due to mild or asymptomatic infections [4], the true number of acute hepatitis B infections is likely to be underestimated.

\section{Classification of risk groups for hepatitis B}

Due to occupational exposure, risk behavior or other non-occupational exposure or preexisting diseases, some subgroups are likely to be at increased risk of HBV infection, or are at increased risk of complications and chronification in the case of infection. In addition to the routine recommendation of vaccination of all infants, STIKO therefore recommends vaccinating these risk groups against hepatitis $B$ to protect them against infection and to prevent transmission.

In the previous version of the recommendation, vaccination against hepatitis B was recommended for eight indication groups [5]. For the revised recommendation, these were re-classified into three groups, supplemented by a recommendation for at-risk travelers. Examples are provided for each of the three groups. STIKO emphasizes that these examples should serve merely for orientation and that they are not intended to represent a definitive list of indication groups for vaccination against hepatitis $B$. In particular, STIKO emphasizes that an individual risk assessment is mandatory, since some of the indication groups include individuals with varying risk of exposure. Furthermore, STIKO underlines that the absence of person groups in the revised recommendation who were explicitly mentioned in the previous version does not mean that these persons should not be vaccinated. Instead, the individual risk of these persons should be assessed to assign them to one of the new indication groups.

By orientating the literature search (search terms: hepatitis B; epidemiology; prevalence; Europe; e.g., HIV, drug use, hemodialysis etc), it was verified that the examples of groups of persons named are either at increased risk of exposure to $\mathrm{HBV}$ or are at increased risk of severe disease due to HBV infection. In the following, relevant references are given for each group (for details, see $\bullet$ Tab. 1, 2, and - Tab.3):

Bundesgesundheitsbl 2013 · 56:1565-1576 DOI 10.1007/s00103-013-1845-8

(c) Springer-Verlag Berlin Heidelberg 2013

T. Harder · C. Remschmidt · G. Falkenhorst · R. Zimmermann · H. Hengel · T. Ledig •

H. Oppermann $\cdot$ S. Zeuzem $\cdot$ S. Wicker

Background paper to the revised recommendation for hepatitis B vaccination of persons at particular risk and for hepatitis B postexposure prophylaxis in Germany

\section{Abstract}

The German Standing Committee on Vaccination (Ständige Impfkommission, STIKO) recommends vaccinating risk groups against hepatitis $B$ and gives advice for postexposure prophylaxis. STIKO has recently revised this recommendation, focusing on: (i) classification of risk groups, (ii) duration of protection after primary immunization, and (iii) anti-HBs threshold that defines successful hepatitis $B$ vaccination. Orientating literature reviews were performed for the first objective. Examples of population subgroups at increased risk were identified and classified into three indication groups. Systematic reviews on the duration of vaccine-induced protection identified one randomized controlled trial (RCT) and nine cohort studies. When applying the grading of recommendation, assessment, development, and evaluation (GRADE) methodology, evidence from RCTs was considered of very low quality regarding the question of whether hepatitis $B$ can be prevented for 15 years after successful primary vaccination (anti-HBs $\geq 10 \mathrm{IU} / \mathrm{l}$ ) with a vaccine efficacy of
$96 \%$ against chronic hepatitis, $89 \%$ against HBsAg positivity, and $73 \%$ against isolated anti-HBc positivity. However, seven cohort studies showed that no cases of clinical hepatitis $\mathrm{B}$ or $\mathrm{HBsAg}$ positivity occurred during a maximum follow-up period of 10 years in settings comparable to the situation in Germany when anti-HBs $\geq 10 \mathrm{lU} / \mathrm{I}$ was used to indicate vaccination success. Less than $1 \%$ of vaccinated study participants had isolated anti$\mathrm{HBC}$ positivity. GRADE assessment of two cohort studies revealed that evidence of very low quality exists that the use of anti-HBs $\geq 100 \mathrm{IU} / \mathrm{I}$ to measure vaccination success leads to a lower frequency of anti-HBc positivity during follow-up than the use of anti-HBs $\geq 10$ IU/I. The recommendation was revised according to this evidence.

\section{Keywords}

Hepatitis B vaccination - Duration of protection - Vaccination recommendation . Standing committee on vaccination (STIKO) . Germany

\section{Hintergrundpapier zu den überarbeiteten STIKO-Empfehlungen für die Hepatitis-B-Indikationsimpfung und postexpositionelle Hepatitis-B-Prophylaxe}

\section{Zusammenfassung}

Die Ständige Impfkommission (STIKO) empfiehlt die Impfung von Risikogruppen gegen Hepatitis B (Indikationsimpfung) und die Postexpositionsprophylaxe. Diese Empfehlung wurde überarbeitet, unter Fokussierung auf i) die Risikogruppen, ii) die Schutzdauer nach Grundimmunisierung und iii) den Schwellenwert von Anti-HBs als Impferfolgskriterium. Risikogruppen wurden mittels orientierender Literaturrecherche identifiziert. Drei Indikationsgruppen wurden beispielhafte Personengruppen zugeordnet. Systematische Literaturrecherchen zur Schutzdauer nach Grundimmunisierung identifizierten eine randomisierte kontrollierte Studie (RCT) und 9 Kohortenstudien. Die Evidenzqualität wurde mittels Grading of Recommendation, Assessment, Development, and Evaluation (GRADE)-Methodik bewertet. Die Qualität der Evidenz aus RCTs dafür, dass Hepatitis $B$ für eine Dauer von 15 Jahren nach erfolgreicher Grundimmunisierung (Anti-HBs $\geq 10 \mathrm{IE} / \mathrm{l})$ mit einer Effektivität von $96 \%$ für chronische Hepatitis B, 89\% für HBsAg-Posi- tivität und 73\% für isolierte Anti-HBc-Positivität verhindert wird, wurde als sehr gering bewertet. Sieben Kohortenstudien zeigten, dass für eine Dauer von maximal 10 Jahren unter mit Deutschland vergleichbaren Bedingungen keine Fälle von klinischer Hepatitis B oder HBsAg-Positivität auftraten, wenn Anti$\mathrm{HBs} \geq 10$ IE/I als Impferfolgskriterium verwendet wurde. Weniger als $1 \%$ der geimpften Probanden hatten isolierte Anti-HBc-Positivität. Die GRADE-Bewertung von 2 Kohortenstudien ergab, dass Evidenz von sehr geringer Qualität dafür vorliegt, dass die Verwendung des Impferfolgskriteriums Anti-HBs $\geq 100$ IE/I zu einer geringeren Häufigkeit von Anti-HBcPositivität führt als die Verwendung des Kriteriums Anti-HBs $\geq 10$ IE/l. Die Impfempfehlung wurde entsprechend dieser Evidenzlage überarbeitet.

\section{Schlüsselwörter}

Hepatitis B-Impfung · Dauer des Schutzes . Impfempfehlung · Ständige Impfkommission (STIKO) · Deutschland 


\begin{tabular}{|c|c|c|c|}
\hline Group of persons & Study & Study setting & Results \\
\hline \multirow[t]{3}{*}{ HIV-positive persons } & $\begin{array}{l}\text { Konopnicki et al. } \\
\text { [66] }\end{array}$ & $\begin{array}{l}\text { Cohort study (EuroSIDA } \\
\text { Cohort, } n=9802 \text { ) from } 72 \text { HIV } \\
\text { centers, Europe }\end{array}$ & $\begin{array}{l}\text { HBsAg was detected in } 498 \text { ( } 8.7 \%) \text { patients. Chronic hepatitis B in- } \\
\text { creased liver-associated mortality in HIV-infected patient, but had no } \\
\text { impact on progression to AIDS or on response to antiretroviral therapy }\end{array}$ \\
\hline & Koziel et al. [67] & Review & $\begin{array}{l}\text { HBV coinfections are common in HIV patients due to similar transmis- } \\
\text { sion route, with a frequency of 5\%-10\% in the US and } 20 \%-30 \% \text { in } \\
\text { Asia }\end{array}$ \\
\hline & Reuter et al. [68] & $\begin{array}{l}\text { Cohort study ( } \mathrm{n}=918) \text {, Ger- } \\
\text { many }\end{array}$ & $\begin{array}{l}\text { Current or previous HBV infection was detected in } 43.4 \% \text { of patients. } \\
\text { HBsAg was detected in } 4.5 \% \text { and HBV-DNA in } 6.1 \% \text { of cases }\end{array}$ \\
\hline \multirow[t]{2}{*}{ Hepatitis C-coinfection } & Chu et al. [6] & $\begin{array}{l}\text { Review ( } n>5000) \text {, Europe } \\
\text { and Asia }\end{array}$ & $\begin{array}{l}\text { In hepatitis B/C coinfection, the majority of studies shows severe liver } \\
\text { damage, high prevalence of liver cirrhosis and an increased incidence } \\
\text { of hepatocellular carcinoma, compared to patients without coinfec- } \\
\text { tion }\end{array}$ \\
\hline & Amin et al. [7] & $\begin{array}{l}\text { Retrospective study (surveil- } \\
\text { lance data, } n>120,000) \\
\text { Australia }\end{array}$ & $\begin{array}{l}\text { Compared to the general population, persons with viral hepatitis had } \\
\text { an increased risk of death due to liver-associated disease, which was } \\
\text { highest in hepatitis B/C-coinfected patients (standardized mortality } \\
\text { ratio: } 32.9 \text { vs. } 12.2 \text { for patients without co-infection) }\end{array}$ \\
\hline \multirow[t]{3}{*}{ Patients on hemodialysis } & Burdick et al. [8] & $\begin{array}{l}\text { Cross-sectional study } \\
(\mathrm{n}=8615) \text { from } 308 \text { dialysis } \\
\text { centers in Europe and the US }\end{array}$ & $\begin{array}{l}\text { In Germany, the adjusted prevalence of hepatitis } \mathrm{B} \text { (clinical or } \mathrm{HBsAg} \\
\text { positivity) in this patient group was } 4.6 \%\end{array}$ \\
\hline & Lanini et al. [9] & $\begin{array}{l}\text { Systematic review of out- } \\
\text { breaks ( } n=471 \text { in } 33 \text { out- } \\
\text { breaks) in the US and Europe }\end{array}$ & $\begin{array}{l}\text { The majority of hepatitis B outbreaks occurred in dialysis units ( } 30.3 \% \\
\text { of outbreaks, followed by } 21.2 \% \text { on medical wards) }\end{array}$ \\
\hline & Kliem et al. [10] & $\begin{array}{l}\text { Cohort study }(n=1,633) \text {, } \\
\text { Germany }\end{array}$ & $\begin{array}{l}\text { Prevalence of HBsAg positivity in this group declined from } 4.6 \% \text { be- } \\
\text { tween } 1995 \text { and } 1999 \text { to } 2.0 \% \text { between } 2000 \text { and } 2002 \text {. It was, howev- } \\
\text { er, still substantially higher than in the general population in Germany }\end{array}$ \\
\hline
\end{tabular}

- Indication group 1: Persons at risk of severe hepatitis B due to existing or expected immunodeficiency or -suppression or due to other preexisting diseases.Examples: HIV-positive individuals, hepatitis $\mathrm{C}$-positive persons $[6,7]$, patients on hemodialysis $[8,9$, $10]$.

- Indication group 2: Persons at increased risk of non-occupational exposure.Examples: Persons living together with HBsAg carriers $[11,12$, 13], persons at high risk of acquiring hepatitis $B$ by sexual contact $[11,14$, $15]$, people who inject drugs $[14,16$, $17]$, prison inmates $[18,19,20]$, psychiatric inpatients [21, 22].

- Indication group 3: Persons at increased risk of occupational exposure.Examples: Health care personnel (HCP) at risk of exposure (including trainees, laboratory personnel, cleaning personnel) $[23,24,25]$, first aiders [26, 27], police officers [29], personnel of facilities where an increased prevalence of $\mathrm{HBV}$-infected persons is likely to be present (e.g., correctional facilities, asylum seeker shelters, homes for the handicapped) $[18,19$, 20, 27, 28, 29].

\section{Duration of protection after primary vaccination against hepatitis B}

A systematic literature review was conducted on the duration of protection against hepatitis B after successful primary vaccination at the age of $\geq 1$ year. The review aimed at identifying long-term studies that investigated the incidence of hepatitis $B$ breakthrough infections in persons who had received primary vaccination without subsequent booster vaccinations. "Breakthrough infection" but not the level of anti-HBs during follow-up was defined as the primary outcome, since loss of measurable anti-HBs after successful primary vaccination does not indicate a loss of protection against hepatitis $\mathrm{B}$ infection, probably due to immunological memory [30]. Therefore, only the presence of a breakthrough infection definitely indicates loss of protection against HBV.

The evidence assessment process was conducted according to the SOP of
STIKO for the systematic development of vaccination recommendations [1]. Following the methodology of the GRADE Working Group [31], patient-relevant outcomes were defined and rated regarding their importance for decision-making.

The following outcomes, which are indicators for breakthrough infections after successful primary vaccination, were rated as "critical" or "important":

\section{CRITICAL:}

- Death due to hepatitis B

- Any clinical hepatitis B

- Acute hepatitis B

- Chronic hepatitis B

- HBsAg positivity

- HBV DNA positivity

\section{IMPORTANT:}

- Anti-HBc positivity

Taking these outcomes into consideration, a systematic review of the published literature was conducted using the databases MEDLINE, EMBASE, SciSearch, Cochrane Central Register of Controlled Trials, and Cochrane Database of Systematic Reviews (search terms: "hepatitis B"; 
Tab. 2 Literature data on groups of persons belonging to indication group 2: persons at increased risk of non-occupational exposure

\begin{tabular}{|c|c|c|c|}
\hline $\begin{array}{l}\text { Group of } \\
\text { persons }\end{array}$ & Study & Study setting & Results \\
\hline \multirow{3}{*}{$\begin{array}{l}\text { Persons liv- } \\
\text { ing together } \\
\text { with HBsAg } \\
\text { carriers }\end{array}$} & $\begin{array}{l}\text { Robert Koch Institute } \\
\text { [11] }\end{array}$ & $\begin{array}{l}\text { Notification data, Ger- } \\
\text { many }\end{array}$ & $\begin{array}{l}\text { Living together with an } \mathrm{HBsAg} \text { carrier was reported in } 35 \text { cases ( } 5 \% \text { of all notifications) } \\
\text { as possible cause of infection }\end{array}$ \\
\hline & Craxi et al. [12] & Cohort study, Italy & $\begin{array}{l}\text { Transmission in households with HBsAg carriers plays a major role in spread of hepati- } \\
\text { tis B, particularly among siblings }\end{array}$ \\
\hline & Franks et al. [13] & Cohort study, US & $\begin{array}{l}\text { HBsAg carriers can transmit hepatitis B within households, but also between house- } \\
\text { holds }\end{array}$ \\
\hline \multirow[t]{3}{*}{$\begin{array}{l}\text { Persons with } \\
\text { high-risk } \\
\text { sexual be- } \\
\text { havior }\end{array}$} & van Houdt et al. [14] & $\begin{array}{l}\text { Cohort study }(n=1862) \text {, } \\
\text { the Netherlands }\end{array}$ & $\begin{array}{l}\text { Between } 1984 \text { and 2002, hepatitis B serology was analyzed in } 1862 \text { sera of men who } \\
\text { have sex with men (MSM). Of these, } 44 \% \text { were anti-HBc-positive at study entry. In to- } \\
\text { tal, } 64 \text { MSM showed seroconversion during the course of the study and } 23 \% \text { of these } \\
\text { developed chronic infection }\end{array}$ \\
\hline & $\begin{array}{l}\text { Robert Koch Institute } \\
\text { [11] }\end{array}$ & $\begin{array}{l}\text { Notification data, Ger- } \\
\text { many }\end{array}$ & $\begin{array}{l}\text { Sexual transmission was reported in } 43 \text { cases ( } 49 \% \text { of cases with reliable data on } \\
\text { mode of transmission), thus representing the major mode of transmission. This in- } \\
\text { cluded } 17 \text { cases ( } 40 \% \text { of cases with sexual transmission) with homosexual contacts } \\
\text { among men }\end{array}$ \\
\hline & Veldhuijzen et al. [15] & $\begin{array}{l}\text { Notification data, the } \\
\text { Netherlands }\end{array}$ & $\begin{array}{l}\text { The majority of notified cases (59\%) were caused by sexual contacts. Of these, } 52 \% \\
\text { were homosexual contacts }\end{array}$ \\
\hline \multirow[t]{3}{*}{$\begin{array}{l}\text { People who } \\
\text { inject drugs }\end{array}$} & Nelson et al. [16] & Systematic review & $\begin{array}{l}\text { For Germany, anti-HBc prevalence in i.v. drug users was estimated to be } 53 \% \text { in } 2001- \\
2003 \text {. For the same period, } \mathrm{HBsAg} \text { prevalence was } 6.0 \%-8.4 \% \text { in this risk group }\end{array}$ \\
\hline & Brack [17] & $\begin{array}{l}\text { Retrospective cohort } \\
\text { study ( }=1791 \text { ) }\end{array}$ & Prevalence of hepatitis B (defined as antibodies against HBV) was $41.4 \%$ in this group \\
\hline & van Houdt et al. [14] & $\begin{array}{l}\text { Cohort study }(n=1862) \\
\text { 1984-2002 }\end{array}$ & $\begin{array}{l}83 \text { i.v. drug users showed anti-HBc seroconversion during the course of the study. Of } \\
\text { these, } 28 \% \text { developed chronic infection }\end{array}$ \\
\hline \multirow[t]{3}{*}{$\begin{array}{l}\text { Prison in- } \\
\text { mates }\end{array}$} & Removille et al. [18] & $\begin{array}{l}\text { Cross-sectional study, } \\
\text { Luxembourg }\end{array}$ & Prevalence of acute or previous hepatitis B was $34.8 \%$ in prison inmates \\
\hline & Gupta et al. [19] & Review, US & $\begin{array}{l}\text { In the US, prevalence of hepatitis B is five times higher in prison inmates than in the } \\
\text { general population }\end{array}$ \\
\hline & Khan [20] & $\begin{array}{l}\text { Serological cross-sec- } \\
\text { tional study }(n=1124) \text {, } \\
\text { US }\end{array}$ & $\begin{array}{l}\text { At study entry, active or previous hepatitis B was diagnosed in } 20.5 \% \text { of prison } \\
\text { inmates. Acute or chronic hepatitis B was present in } 1 \% \text {, while } 18.5 \% \text { had previous } \\
\text { hepatitis B infection }\end{array}$ \\
\hline \multirow[t]{2}{*}{$\begin{array}{l}\text { Psychiatric } \\
\text { inpatients }\end{array}$} & Velinga et al. [21] & $\begin{array}{l}\text { Review ( } \mathrm{n}>8000) \text {, Eu- } \\
\text { rope, US, and others }\end{array}$ & $\begin{array}{l}\text { Prevalence of HBsAg positivity was increased in patients with mental handicaps in } \\
\text { nearly all study settings, ranging from } 0 \% \text { to } 53 \%\end{array}$ \\
\hline & Asensio et al. [22] & $\begin{array}{l}\text { Cohort study } \\
(n=171), \text { Spain }\end{array}$ & $\begin{array}{l}\text { In total, } 46.8 \% \text { of patients were anti-HBc positive and anti-HBs positive, } 24.6 \% \text { were } \\
\text { anti-HBc positive only, } 8.8 \% \text { were } \mathrm{HBsAg} \text { positive and anti-HBc positive. Only } 18.7 \% \text { of } \\
\text { patients were negative for all HBV markers }\end{array}$ \\
\hline
\end{tabular}

Tab. 3 Literature data on groups of persons belonging to indication group 3: persons at increased risk of occupational exposure

\begin{tabular}{|c|c|c|c|}
\hline Group of persons & Study & Study setting & Results \\
\hline \multirow{3}{*}{$\begin{array}{l}\text { Health care per- } \\
\text { sonnel including } \\
\text { trainees, as well as } \\
\text { laboratory and clean- } \\
\text { ing personnel }\end{array}$} & $\begin{array}{l}\text { Danzmann et } \\
\text { al. [23] }\end{array}$ & Systematic review & HBV was among the predominant pathogens in 152 nosocomial outbreaks \\
\hline & Wicker et al. [24] & Cohort study, Germany & $\begin{array}{l}\text { Prevalence of hepatitis B in hospital patients was nine times higher than in the } \\
\text { general population, thereby putting health care personnel at increased risk, par- } \\
\text { ticularly due to needlestick injuries }\end{array}$ \\
\hline & Janzen et al. [25] & $\begin{array}{l}\text { Case-control study } \\
(\mathrm{n}=3770), \text { Germany }\end{array}$ & $\begin{array}{l}\text { Prior to implementation of vaccination, prevalence of HBsAg positivity was } 2.2 \% \text {, } \\
\text { while anti-HBs prevalence was } 11.7 \% \text {. Physicians ( } 18.2 \%) \text {, nursing staff }(20.1 \%), \\
\text { and cleaning personnel ( } 26.3 \%) \text { were most often affected }\end{array}$ \\
\hline \multirow[t]{2}{*}{$\begin{array}{l}\text { First aiders, police } \\
\text { officers }\end{array}$} & $\begin{array}{l}\text { Rischitelli et al. } \\
{[26]}\end{array}$ & Review, US & $\begin{array}{l}\text { First aiders are at increased risk of infection, comparable to the risk in health care } \\
\text { personnel }\end{array}$ \\
\hline & Lorentz et al. [27] & $\begin{array}{l}\text { Cross-sectional study } \\
\text { ( } \mathrm{n}=803) \text {, US }\end{array}$ & $\begin{array}{l}\text { About } 30 \% \text { of police officers reported at least one needlestick injury. Only } 39 \% \text { of } \\
\text { these sought medical care }\end{array}$ \\
\hline \multirow{2}{*}{$\begin{array}{l}\text { Personnel in facilities } \\
\text { where an increased } \\
\text { prevalence of HBV- } \\
\text { infected persons is } \\
\text { likely to be present }\end{array}$} & Breuer et al. [28] & Cohort study, US & $\begin{array}{l}\text { Teachers and school children are at increased risk of hepatitis B infection if they } \\
\text { come in contact with an HBsAg carrier in the classroom }\end{array}$ \\
\hline & Remis et al. [29] & Cohort study, Canada & $\begin{array}{l}\text { Teachers at schools for the mentally handicapped can be at increased risk of hepa- } \\
\text { titis B infection }\end{array}$ \\
\hline
\end{tabular}




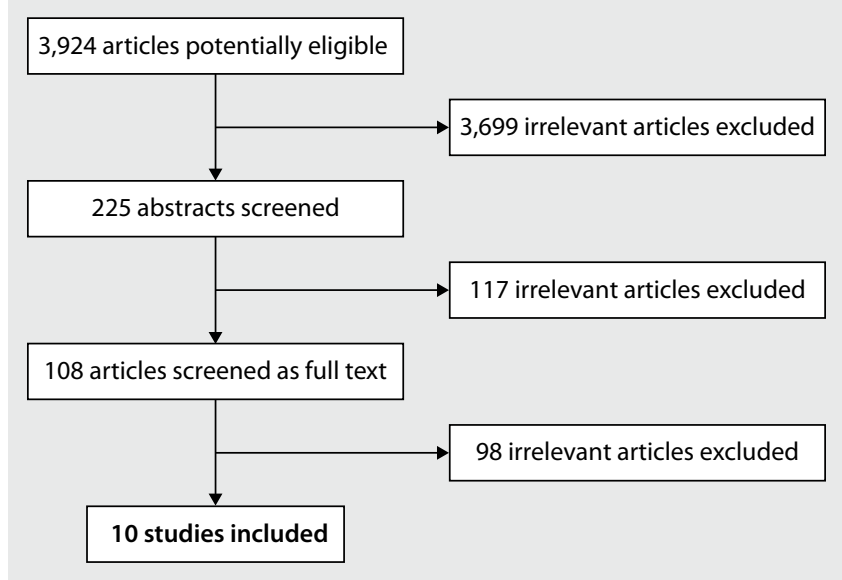

Fig. $1<$ Flow chart of the systematic review

"vaccin*"; "immunization"; "random*"; "blind"”; "placebo"; "meta-analys ${ }^{\star ” ; ~ " c o-~}$ hort"; "time series"; "case-control"; "ecological"; "cross-sectional"). Additionally, the results of four Cochrane Reviews [32, $33,34,35]$ and one meta-analysis [36] relevant to the topic were considered.

The literature search yielded 3924 publications. Studies meeting the following inclusion criteria were included:

1. Randomized controlled trial (RCT) or observational study (all study designs)

2. Age at start of primary vaccination: $\geq 1$ year

3. No previous hepatitis B infection (proven by serological testing)

4. Vaccination with a hepatitis B vaccine according to the schedule 0-1-6(12) months

5. Success of vaccination evaluated and reported (proven by anti-HBs testing)

6. No booster vaccinations during follow-up

7. Duration of follow-up $\geq 5$ years

8. At least one of the above-mentioned important or critical outcomes was investigated.

Application of the inclusion criteria led to the identification of one RCT [37] and nine observational studies ([38, 39, 40, 41, 42, 43, 44, 45, 46], see • Fig. 1).

The results of the systematic literature review are reported below in detail, as well as an assessment of the quality of evidence according to GRADE, where applicable. Due to the heterogeneity in study designs and results, a meta-analysis with statistical pooling of results was not performed.

\section{Randomized controlled trials}

The only RCT meeting all inclusion criteria [37] was performed in China, using a plasma-derived vaccine and including 649 participants (vaccine group: 308, placebo group: 341 ; age at vaccination: 14 months). Successful vaccination was defined as anti-HBs $\geq 10$ IU/l after primary vaccination. Participants were followed-up for a period of 15 years, during which the majority of participants left the study (vaccine group: $83 \%$, placebo group: $72 \%)$. At 15 years following primary vaccination, vaccine efficacy was 96\% [95\% confidence interval (CI): 74-99\%] against chronic hepatitis B, 89\% (95\% CI: $12-$ 99\%) against HBsAg positivity, and 73\% (95\% CI: 57-84\%) against isolated anti$\mathrm{HBc}$ positivity.

Based on these data, the quality of evidence was assessed using the GRADE methodology and results summarized in a GRADE evidence profile (• Tab. 4). High loss-to-follow-up rates, which differed between vaccine and placebo groups, were considered to indicate high risk of bias. Evidence was classified as "indirect" considering the nature of the vaccine used in the study (plasma-derived). Because the study was conducted in a region with a high HBsAg carrier prevalence (China), which could have resulted in natural boosting of study participants, evidence was further downgraded for indirectness. In summary, there is very low quality evidence (i.e., very low confidence in the effect estimate) that successful primary vaccination against hepatitis B (indicated by anti-HBs $\geq 10$ IU/l) protects against hepatitis $\mathrm{B}$ over a period of 15 years with the above-mentioned efficacy data.

\section{Observational studies}

All nine observational studies were singlearmed cohort studies [38, 40,41, 42, 45, 46] or arms of former RCTs which were continued as cohort studies [39, 43, 44]. None of the studies included a non-vaccinated control group. In seven out of nine cohort studies, successful vaccination was defined as anti-HBs $\geq 10 \mathrm{IU} / \mathrm{l}$ after primary vaccination $[38,39,40,41,43,45,46]$. In the remaining two studies, results were stratified according to anti-HBs levels after primary vaccination (10-99 IU/l vs. $\geq 100$ IU/l) $[42,44]$.

Study characteristics of the seven single-armed cohort studies, in which vaccination success was defined as anti-HBs $\geq 10 \mathrm{IU} / 1$, are shown in - Tab. 5. The study by But et al. [39] was divided into two sub-studies, since participants were vaccinated with either a plasma-derived or a recombinant vaccine. Duration of follow-up in the seven studies ranged from 5 to 22 years. Cases of clinical hepatitis B or HBsAg positivity were not observed in any of the studies. Cases of isolated anti$\mathrm{HBc}$ positivity were found in five studies, suggesting breakthrough infection [4]. These occurred in $1.7 \%-26 \%$ of participants, mainly in countries with a moderate or high prevalence of HBsAg carriers (e.g., China, India, Iran).

In terms of HBV exposure risk and vaccination, two of the seven cohort study settings were considered to be comparable to Germany. In the Canadian study performed by Gilca et al. [43], 326 children aged 8-10 years were vaccinated with a recombinant vaccine (Engerix $\mathrm{B}^{\circledR}$, GSK) and followed-up over a period of 10 years, during which $15 \%$ of the participants left the study. No cases with HBsAg positivity or isolated anti-HBc positivity were observed during the entire follow-up period. The Belgian study by Van Herck et al. [46] included 188 adult participants (mean age at vaccination: $23.3 \pm 0.28$ years) who were vaccinated with a recombinant vaccine (not further specified) and were followedup for a period of 8 years. Of these participants, $79 \%$ were lost to follow-up. No cases of HBsAg positivity or isolated an- 


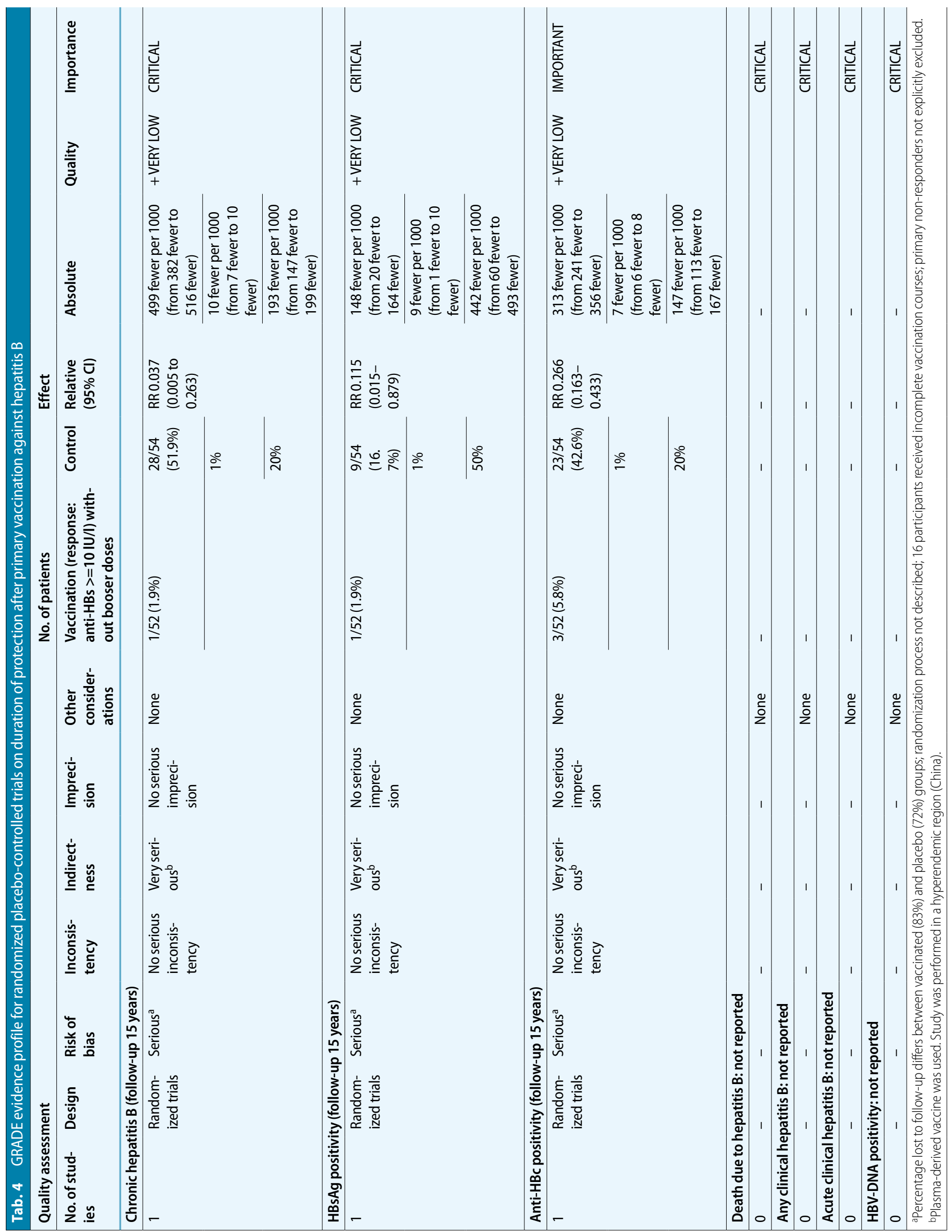


Tab. 5 Cohort studies on the duration of protection after primary vaccination against hepatitis B (vaccination success: anti-HBs $>=10$ IU/I)

\begin{tabular}{|c|c|c|c|c|c|c|c|c|}
\hline Study & No. (final) & $\begin{array}{l}\text { Age at vac- } \\
\text { cination } \\
\text { (years; } \\
\text { median) }\end{array}$ & Country & Participants & Vaccine type & $\begin{array}{l}\text { Duration } \\
\text { of follow- } \\
\text { up (years) }\end{array}$ & $\begin{array}{l}\text { Percentage of } \\
\text { participants } \\
\text { who were lost } \\
\text { to follow-up } \\
(\%)\end{array}$ & $\begin{array}{l}\text { Percentage of } \\
\text { participants } \\
\text { with isolated } \\
\text { anti-HBc posi- } \\
\text { tivity (\%) }\end{array}$ \\
\hline Alavian et al. [38] & 113 & 32 & Iran & Health care personnel & Recombinant & 16 & 43 & 26 \\
\hline But et al. (I) [39] & 17 & 5.6 & China & Children & Recombinant & 22 & 84 & 5.9 \\
\hline But et al. (II) [39] & 21 & 5.3 & China & Children & Plasma-derived & 22 & 80 & 4.8 \\
\hline Chadha et al. [40] & 30 & 37 & India & Laboratory personnel & Recombinant & 10 & 12 & 0 \\
\hline Durlach et al. [41] & 114 & 37 & Argentina & Hospital personnel & Recombinant & 10 & 57 & 1.7 \\
\hline Gilca et al. [43] & 276 & 9 & Canada & School children & Recombinant & 10 & 15 & 0 \\
\hline Mintai et al. [45] & 95 & 14 & China & Children & Plasma-derived & 5 & 0 & 9.5 \\
\hline $\begin{array}{l}\text { Van Herck et al. } \\
\text { [46] }\end{array}$ & 40 & 23 & Belgium & General population & Recombinant & 8 & 79 & 0 \\
\hline
\end{tabular}

ti-HBc positivity were observed in the remaining participants. No cases of acute or chronic hepatitis B were reported in either publication $[43,46]$.

An observational study published by Zanetti et al. [47] was considered to provide additional evidence. Although this study did not meet all inclusion criteria of the systematic review (lack of a definition of vaccination success in the publication), it was considered informative in terms of the investigated population, length of follow-up period, and included parameters. This was a retrospective cohort study performed in Italy which included 446 male army recruits. Participants were vaccinated during childhood with a recombinant vaccine (Engerix B ${ }^{\circledast}$, GSK), had not received booster vaccinations, and were reinvestigated 10 years after primary vaccination. No cases of HBsAg positivity were observed. Isolated anti-HBc positivity was detected in $0.9 \%$ of the participants. None of the participants was positive for HBV DNA.

The quality of evidence from the single-armed cohort studies cannot be assessed by the GRADE methodology because all studies lacked a non-vaccinated comparison group. Taken together, these studies show that no cases with clinical hepatitis or HBsAg positivity occurred during a 10-year follow-up period in settings comparable to Germany (low prevalence of HBsAg carriers; use of recombinant vaccines) when vaccination success was defined as anti-HBs $\geq 10$ IU/l. However, the small numbers of participants in the studies need to be considered: Given the low incidence of hepatitis B in Germany, very large and long-term prospective cohort studies would have been needed to detect breakthrough infections even if vaccine effectiveness was low. In the studies from Europe and North America, less than $1 \%$ of vaccinated participants showed isolated anti-HBc positivity during the follow-up period.

\section{Anti-HBs threshold for the definition of vaccination success}

In order to address the question of whether duration of protection depends on the level of anti-HBs after primary vaccination, studies stratifying results according to the anti-HBs level were analyzed. Such data were available from two cohort studies conducted in Canada [42] and the US [44]. Duval et al. [42] included 328 participants who originated from a study arm of a randomized controlled trial. Participants were $8-10$ years old at the time of primary vaccination with a recombinant vaccine (Recombivax- $\mathrm{HB}^{\oplus}$, Merck) and were followed-up over a period of 5 years. In all, $17 \%$ of the participants left the study during follow-up. By the end of the study, no cases of clinical hepatitis B, HBsAg positivity, or isolated anti-HBc positivity were observed, either in participants who had anti-HBs levels of 10-99 IU/l after primary vaccination $(n=7)$ or in those who had anti-HBs levels of $\geq 100$ IU/l $(n=268)$.
The study by Hadler et al. [44] included 773 participants who originated from the vaccinated study arm of an RCT in homosexual men. At primary vaccination, participants were $29.7 \pm 7.6$ years old. Study participants were vaccinated with a plasma-derived vaccine (Merck) and were followed-up for 5 years. Due to unclear reporting, the proportion of participants who were lost to follow-up could not be calculated. Study results for the outcomes "HBsAg positivity" and "isolated anti-HBc positivity" were stratified according to anti-HBs level after primary vaccination, measured in sample ratio units (SRU). Incidence of isolated anti-HBc positivity was significantly lower in participants with anti-HBs $\geq 100$ SRU (425 participants), as compared to those who had an anti-HBs of 10-99 SRU (210 participants) after vaccination [relative risk (RR): 0.14; 95\% CI: 0.06-0.30]. This was accompanied by a non-significantly lower incidence of HBsAg positivity (RR: 0.49 ; 95\% CI: 0.03-7.86) in the former group.

For the following reasons, the findings of this study need to be interpreted with caution: In addition to the use of a plasma-derived vaccine, the study population experienced a high level of HBV exposure, as shown by a prevalence of HBsAg positivity of $13 \%$ in the study population prior to implementation of the vaccination, indicating a high chance of natural boosting. Furthermore, the lost-to-followup rate was unclear. Finally, the SRUs used in the study to measure anti-HBs are not 


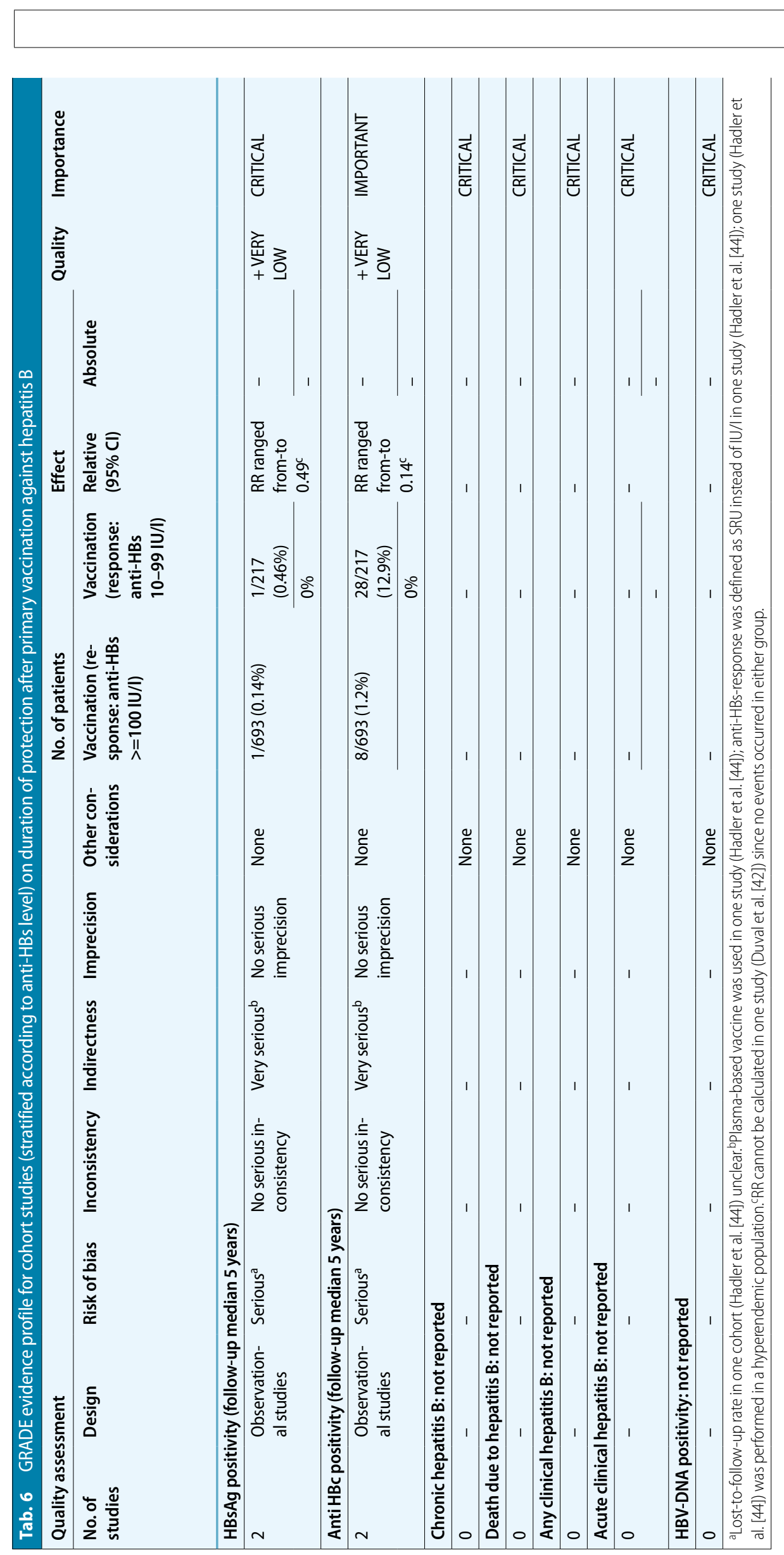

Bundesgesundheitsblatt - Gesundheitsforschung - Gesundheitsschutz 11·2013 $\mid 1573$ 
linearly related to the currently used unit of measurement (IU/l), particularly in the upper measurement range of the assays.

According to GRADE criteria, there is evidence of very low quality (i.e., very low confidence in the effect estimate) that the use of anti-HBs $\geq 100$ IU/l to define successful vaccination leads to a lower frequency of breakthrough infections (measured as anti-HBc positivity) during longterm follow-up (duration: 5 years) than the use of anti-HBs $\geq 10$ IU/l (• Tab. 6).

\section{Synopsis and interpretation of the evidence}

The available evidence is considered sufficient by a number of international committees and expert panels to presume long-term or even life-long protection against hepatitis B after primary vaccination (without booster doses) if the vaccinee's anti-HBs level is $\geq 10$ IU/1 4-8 weeks after vaccination $[48,49,50,51]$.

However, STIKO emphasizes that a synoptic appraisal of the evidence should also consider the diagnostic quality of anti-HBs assays. In a study by Huzly et al. [52], nine commercially available assays that are used to quantify anti-HBs were analyzed. This study detected considerable variation in test results when analyzing identical specimens, resulting in a variation coefficient of $47 \%$. Huzly et al. concluded that no investigated assay was able to provide reliable and reproducible results in the range 5-20 IU/1. Accordingly, the authors consider an anti-HBs of $\geq 10$ IU/l an unreliable threshold to define successful vaccination.

In conclusion, STIKO considers an anti-HBs level of $\geq 100$ IU/l indicative of successful vaccination against hepatitis $B$. This threshold is also recommended by other National Immunization Technical Advisory Groups (NITAGs) in Europe $[53,54,55]$. Since the response to hepatitis $B$ vaccination is influenced by a variety of factors such as age, body weight, smoking behavior, immune status, and genetics $[56,57,58,59,60]$, vaccination success should be demonstrated by testing for anti-HBs in all persons at particular risk vaccinated against hepatitis $\mathrm{B}$.

Controversies exist as to how to manage individuals who remain low respond- ers or non-responders even after two completed vaccination series (total of six doses), i.e., who continue to show anti-HBs levels of $10-99 \mathrm{IU} / 1$ or $<10 \mathrm{IU} / \mathrm{l}$. While CDC's Advisory Committee on Immunization Practices (ACIP) does not recommend further vaccine doses [50], others have described that up to 14 doses are needed to achieve successful vaccination in such cases [61]. Since it is unclear which approach is appropriate, STIKO only names these alternatives without making a recommendation.

Given the epidemiological situation in Germany, STIKO infers from the evidence reviewed above that, in general, no further booster immunizations are needed after successful primary vaccination against hepatitis B in childhood or adulthood. This conclusion has also been drawn by other international public health agencies and expert panels. The World Health Organization (WHO) states that no evidence exists that booster immunizations are needed after routine vaccination against hepatitis B [49]. This position is shared by the US Centers for Disease Control and Prevention (CDC) [50], the Canadian National Advisory Committee on Immunization [62], the European Consensus Group on Hepatitis B Immunity [48], and the Viral Hepatitis Prevention Board [63].

A special situation exists in patients with humoral immune deficiency who show a rapid decline in anti-HBs levels $[64,65]$. Annual testing of anti-HBs levels is recommended by STIKO in these patients (e.g., individuals on hemodialysis).

Furthermore, STIKO assumes that certain individuals in each indication group have a particularly high individual exposure risk, e.g., persons who are in permanent or repeated intimate contact with HBsAg carriers or to the mentioned groups. These persons are at a high cumulative risk of $\mathrm{HBV}$ infection, while waning of immunity cannot be completely ruled out. Therefore, following a conservative approach, STIKO recommends that these persons should be tested for anti-HBs after 10 years, followed by booster vaccination if anti-HBs is $<100 \mathrm{IU} / \mathrm{l}$. Likewise, in case of postexposure prophylaxis, a duration of protection of 10 years after primary vaccination is assumed.

\section{Conclusion}

Given the available evidence, STIKO has drawn the following conclusions which were considered in the revised recommendation:

- In addition to routine infant vaccination against hepatitis $B$, vaccination is recommended for three indication groups. For each of these, relevant examples are provided. However, they should serve as orientation, but are not intended as a definitive list of indications for vaccination against hepatitis $B$.

- Routine serological testing for hepatitis $B$ prior to vaccination is not required.

- For all indication groups, serological testing of vaccination success is recommended, since only successful vaccination (defined as anti-HBs $\geq 100 \mathrm{IU} / \mathrm{I}$ ) assures protection against hepatitis B. In cases of hepatitis B vaccination prior to travel, the need for anti-HBs testing after vaccination should be assessed individually.

- Further testing of anti-HBs and booster immunizations are generally not needed after successful primary vaccination.

- Exceptions to the latter are made in patients with humoral immune deficiency for whom yearly testing of anti-HBs is recommended (booster vaccination if anti-HBs $<100 \mathrm{lU} / \mathrm{l}$ ), as well as in persons who are at particularly high individual exposure risk (anti-HBs testing after 10 years; booster vaccination if anti-HBs <100 IU/I).

- For postexposure immune prophylaxis, duration of protection is assumed to last 10 years after successful vaccination.

\section{Corresponding address}

\section{Dr. T. Harder}

Immunization Unit, Department of

Infectious Disease Epidemiology,

Robert Koch Institute

Seestr. 10, 13353 Berlin

Germany

hardert@rki.de 
Acknowledgment. The authors would like to thank Christian Bogdan, Institute of Microbiology, University Medical Center Erlangen, and Christian Schüttler, National Reference Centre for Hepatitis B, Justus-Liebig University Hospital Gießen, for discussions and comments.

Conflicts of interest. The corresponding author states the following: SZ worked as a consultant for BMS, Gilead, MSD, Novartis and Roche. All other authors state that there are no conflicts of interest.

\section{References}

1. German Standing Committee on Vaccination (STIKO) (2011) Standard operating procedure for the development of evidence-based vaccination recommendations. Available at http://www.rki.de/ EN/Content/Prevention/Vaccination/methodology/methoden_node.html;jsessionid=E99B9D49A BC560639F67973F05D4103C.2_cid390. Accessed 28 August 2013

2. World Health Organization (2013) Introduction of hepatitis $B$ vaccine into childhood immunization services. World Health Organization, Geneva, Switzerland

3. Robert Koch-Institut (2012) Infektionsepidemiologisches Jahrbuch für 2012, Berlin

4. Gerlich WH, Bremer C, Saniewski M et al (2010) Occult hepatitis B virus infection: detection and significance. Dig Dis 28:116-125

5. Ständige Impfkommission (2012) Empfehlungen der Ständigen Impfkommission (STIKO) am Robert Koch-Institut/Stand: Juli 2012. Epidemiol Bull 290291

6. Chu CJ, Lee SD (2008) Hepatitis B virus/hepatitis C virus coinfection: epidemiology, clinical features, viral interactions and treatment. J Gastroenterol Hepatol 23:512-520

7. Amin J, Law MG, Bartlett M et al (2006) Causes of death after diagnosis of hepatitis B or hepatitis $C$ infection: a large community-based linkage study. Lancet 368:938-945

8. Burdick RA, Bragg-Gresham JL, Woods JD et al (2003) Patterns of hepatitis B prevalence and seroconversion in hemodialysis units from three continents: the DOPPS. Kidney Int 63:2222-2229

9. Lanini S, Puro V, Lauria FN et al (2009) Patient to patient transmission of hepatitis B virus: a systematic review of reports on outbreaks between 1992 and 2007. BMC Med 7:15

10. Kliem V, Burg M, Haller H et al (2008) Relationship of hepatitis $B$ or $C$ virus prevalences, risk factors, and outcomes in renal transplant recipients: analysis of German data. Transplant Proc 40:909-914

11. Robert Koch-Institut (2012) Virushepatitis B, C und D im Jahr 2011. Epidemiologisches Bulletin http://wwwrkide/DE/Content/Infekt/EpidBull/Archiv/2012/Ausgaben/38_12pdf? blob=publicationFile. Accessed: 4 Apr 2012 (38/2012)

12. Craxi A, Tine F, Vinci M et al (1991) Transmission of hepatitis $B$ and hepatitis delta viruses in the households of chronic hepatitis B surface antigen carriers: a regression analysis of indicators of risk. Am J Epidemiol 134:641-650

13. Franks AL, Berg CJ, Kane MA et al (1989) Hepatitis $B$ virus infection among children born in the United States to Southeast Asian refugees. N Engl J Med 321:1301-1305
14. Houdt R van, Bruisten SM, Speksnijder AG, Prins M (2012) Unexpectedly high proportion of drug users and men having sex with men who develop chronic hepatitis B infection. J Hepatol 57:529-533

15. Veldhuijzen IK, Smits LJ, Laar MJ van de (2005) The importance of imported infections in maintaining hepatitis B in The Netherlands. Epidemiol Infect 133:113-119

16. Nelson PK, Mathers BM, Cowie B et al (2011) Global epidemiology of hepatitis $B$ and hepatitis $C$ in people who inject drugs: results of systematic reviews. Lancet 378:571-583

17. Brack J (2002) Die Hepatitiden B und C bei drogenabhängigen Patienten: Eine epidemiologische Studie. Suchttherapie (Suppl 1):S3-S10

18. Removille N, Origer A, Couffignal S et al (2011) A hepatitis $A, B, C$ and HIV prevalence and risk factor study in ever injecting and non-injecting drug users in Luxembourg associated with HAV and HBV immunisations. BMC Public Health 11:351

19. Gupta S, Altice FL (2009) Hepatitis B virus infection in US correctional facilities: a review of diagnosis, management, and public health implications. J Urban Health 86:263-279

20. Khan AJ, Simard EP, Bower WA et al (2005) Ongoing transmission of hepatitis $B$ virus infection among inmates at a state correctional facility. Am J Public Health 95:1793-1799

21. Vellinga A, Van Damme P, Meheus A (1999) Hepatitis $B$ and $C$ in institutions for individuals with intellectual disability. J Intellect Disabil Res 43(Pt 6):445-453

22. Asensio F, Bayas JM, Bertran MJ, Asenjo MA (2000) Prevalence of hepatitis $B$ infection in long-stay mentally handicapped adults. Eur J Epidemiol 16:725-729

23. Danzmann L, Gastmeier P, Schwab F, Vonberg RP (2013) Health care workers causing large nosocomial outbreaks: a systematic review. BMC Infect Dis 13:98

24. Wicker S, Cinatl J, Berger A et al (2008) Determination of risk of infection with blood-borne pathogens following a needlestick injury in hospital workers. Ann Occup Hyg 52:615-622

25. Janzen J, Tripatzis I, Wagner U et al (1978) Epidemiology of hepatitis B surface antigen ( $\mathrm{HBsAg}$ ) and antibody to HBsAg in hospital personnel. J Infect Dis 137:261-265

26. Rischitelli G, Harris J, McCauley L et al (2001) The risk of acquiring hepatitis $\mathrm{B}$ or $\mathrm{C}$ among public safety workers: a systematic review. Am J Prev Med 20:299-306

27. Lorentz J, Hill L, Samimi B (2000) Occupational needlestick injuries in a metropolitan police force. Am J Prev Med 18:146-150

28. Breuer B, Friedman SM, Millner ES et al (1985) Transmission of hepatitis $B$ virus to classroom contacts of mentally retarded carriers. JAMA 254:3190-3195

29. Remis RS, Rossignol MA, Kane MA (1987) Hepatitis $B$ infection in a day school for mentally retarded students: transmission from students to staff. Am J Public Health 77:1183-1186

30. Bauer T, Jilg W (2006) Hepatitis B surface antigenspecific $T$ and $B$ cell memory in individuals who had lost protective antibodies after hepatitis $B$ vaccination. Vaccine 24:572-577

31. Atkins D, Best D, Briss PA et al (2004) Grading quality of evidence and strength of recommendations. BMJ 328:1490

32. Chen W, Gluud C (2005) Vaccines for preventing hepatitis B in health-care workers. Cochrane Database Syst Rev CD000100
33. Mathew JL, El Dib R, Mathew PJ et al (2008) Hepatitis $B$ immunisation in persons not previously exposed to hepatitis $B$ or with unknown exposure status. Cochrane Database Syst Rev CD006481

34. Poorolajal J, Mahmoodi M, Haghdoost $A$ et al (2010) Booster dose vaccination for preventing hepatitis B. Cochrane Database Syst Rev CD008256

35. Schroth RJ, Hitchon CA, Uhanova J et al (2004) Hepatitis $B$ vaccination for patients with chronic renal failure. Cochrane Database Syst Rev CD003775

36. Poorolajal J, Mahmoodi M, Majdzadeh R et al (2010) Long-term protection provided by hepatitis $B$ vaccine and need for booster dose: a meta-analysis. Vaccine 28:623-631

37. Liao SS, Li RC, Li H et al (1999) Long-term efficacy of plasma-derived hepatitis B vaccine: a 15-year follow-up study among Chinese children. Vaccine 17:2661-2666

38. Alavian SM, Mansouri S, Abouzari M et al (2008) Long-term efficacy of hepatitis $B$ vaccination in healthcare workers of Oil Company Hospital, Tehran, Iran (1989-2005). Eur J Gastroenterol Hepatol 20:131-134

39. But DY, Lai CL, Lim WL et al (2008) Twenty-two years follow-up of a prospective randomized trial of hepatitis $B$ vaccines without booster dose in children: final report. Vaccine 26:6587-6591

40. Chadha MS, Arankalle VA (2000) Ten-year serological follow up of hepatitis B vaccine recipients. Indian J Gastroenterol 19:168-171

41. Durlach R, Laugas S, Freuler CB et al (2003) Tenyear persistence of antibody to hepatitis $B$ surface antigen in healthcare workers vaccinated against hepatitis B virus, and response to booster vaccination. Infect Control Hosp Epidemiol 24:773-776

42. Duval B, Gilca V, Boulianne N et al (2005) Comparative long term immunogenicity of two recombinant hepatitis $B$ vaccines and the effect of a booster dose given after five years in a low endemicity country. Pediatr Infect Dis J 24:213-218

43. Gilca V, De Serres G, Boulianne N et al (2009) Antibody kinetics among $8-10$ years old respondents to hepatitis $B$ vaccination in a low endemic country and the effect of a booster dose given 5 or 10 years later. Vaccine 27:6048-6053

44. Hadler SC, Francis DP, Maynard JE et al (1986) Long-term immunogenicity and efficacy of hepatitis $B$ vaccine in homosexual men. N Engl J Med 315:209-214

45. Mintai Z, Kezhou L, Lieming D, Smego RA Jr (1993) Duration and efficacy of immune response to hepatitis $B$ vaccine in high-risk Chinese adolescents. Clin Infect Dis 16:165-167

46. Van Herck K, Van Damme P, Thoelen S, Meheus A (1998) Long-term persistence of anti-HBs after vaccination with a recombinant DNA yeast-derived hepatitis $B$ vaccine: 8-year results. Vaccine 16:1933-1935

47. Zanetti AR, Mariano A, Romano L et al (2005) Long-term immunogenicity of hepatitis $B$ vaccination and policy for booster: an Italian multicentre study. Lancet 366:1379-1384

48. No authors listed (2000) Are booster immunisations needed for lifelong hepatitis B immunity? European Consensus Group on Hepatitis B Immunity. Lancet 355:561-565

49. No authors listed (2009) Hepatitis B vaccines. Releve epidemiologique hebdomadaire/Section d'hygiene du Secretariat de la Societe des Nations $=$ Weekly epidemiological record/Health Section of the Secretariat of the League of Nations 84:405419 
50. Advisory Committee on Immunization $P$, Centers for Disease C, Prevention (2011) Immunization of health-care personnel: recommendations of the Advisory Committee on Immunization Practices (ACIP). MMWR Recomm Rep 60:1-45

51. Puro V, De Carli G, Cicalini S et al (2005) European recommendations for the management of healthcare workers occupationally exposed to hepatitis B virus and hepatitis C virus. Euro Surveill 10:260264

52. Huzly D, Schenk T, Jilg W, Neumann-Haefelin D (2008) Comparison of nine commercially available assays for quantification of antibody response to hepatitis B virus surface antigen. J Clin Microbiol 46:1298-1306

53. Department of Health (2006) Immunisation against infectious disease. Department of Health, London

54. Bundesamt für Gesundheit und Eidgenössische Kommission für Impffragen (2012) Schweizerischer Impfplan 2012

55. National Immunisation Advisory Committee of the Royal College of Physicians of Ireland (2008) Immunisation Guidelines for Ireland

56. Alper CA, Kruskall MS, Marcus-Bagley D et al (1989) Genetic prediction of nonresponse to hepatitis B vaccine. N Engl J Med 321:708-712

57. Averhoff F, Mahoney F, Coleman P et al (1998) Immunogenicity of hepatitis B Vaccines. Implications for persons at occupational risk of hepatitis $B$ virus infection. Am J Prev Med 15:1-8

58. Shaw FE Jr, Guess HA, Roets JM et al (1989) Effect of anatomic injection site, age and smoking on the immune response to hepatitis $B$ vaccination. Vaccine 7:425-430

59. Weber DJ, Rutala WA, Samsa GP et al (1985) Obesity as a predictor of poor antibody response to hepatitis B plasma vaccine. JAMA 254:3187-3189

60. Wood RC, MacDonald KL, White KE et al (1993) Risk factors for lack of detectable antibody following hepatitis $B$ vaccination of Minnesota health care workers. JAMA 270:2935-2939

61. Heininger U, Gambon M, Gruber V, Margelli D (2010) Successful hepatitis B immunization in nonand low responding health care workers. Hum Vaccin 6:725-728

62. Canadian National Advisory Committee on Immunization (2012) Canadian immunization guide. Available at http://www.phac-aspc.gc.ca/publicat/ cig-gci/index-eng.php. Accessed 04 October 2013

63. Viral Hepatitis Prevention Board (2012) Conclusions (Meeting News). Viral Hepatitis 20:26-27

64. Chaves SS, Daniels D, Cooper BW et al (2011) Immunogenicity of hepatitis $B$ vaccine among hemodialysis patients: effect of revaccination of nonresponders and duration of protection. Vaccine 29:9618-9623

65. Stevens CE, Alter HJ, Taylor PE et al (1984) Hepatitis $B$ vaccine in patients receiving hemodialysis. Immunogenicity and efficacy. N Engl J Med 311:496501

66. Konopnicki D, Mocroft A, Wit S de et al (2005) Hepatitis $B$ and HIV: prevalence, AIDS progression, response to highly active antiretroviral therapy and increased mortality in the EuroSIDA cohort. Aids 19:593-601

67. Koziel MJ, Peters MG (2007) Viral hepatitis in HIV infection. N Engl J Med 356:1445-1454

68. Reuter S, Oette M, Wilhelm FC et al (2011) Prevalence and characteristics of hepatitis $B$ and $C$ virus infections in treatment-naive HIV-infected patients. Med Microbiol Immunol 200:39-49 